\title{
Biodegradable Natural Polymers for Biomedical Applications
}

\author{
Israt Parveen \\ Department of Textile Engineering, Mawlana Bhashani Science and Technology University, Santosh, Tangail-1902, Bangladesh \\ Institute of Radiation and Polymer Technology, Atomic Energy Research Establishment, Dhaka, Bangladesh \\ Md. Iqbal Mahmud \\ Department of Textile Engineering, Mawlana Bhashani Science and Technology University, Santosh, Tangail-1902, Bangladesh \\ Ruhul A. Khan* \\ Institute of Radiation and Polymer Technology, Atomic Energy Research Establishment, Dhaka, Bangladesh
}

\begin{abstract}
Biodegradable polymers as biomaterial are hotcake nowadays especially in medical and pharmaceutical applications. The present contribution comprises an overview of the biodegradable polymers for various biomedical applications. To meet the need of modern medicine, their physical, chemical, functional, biomechanical are highlighted as well as biodegradation properties like non-toxicity, low antigenicity, high bio-activity etc. This review summarizes the emerging and innovative field of biopolymer with the focus on tissue engineering, temporary implants, wound healing, and drug delivery applications etc.
\end{abstract}

Keywords: Biodegradable polymer; Biomaterials; Tissue engineering; Drug delivery etc.

(c) (i) CC BY: Creative Commons Attribution License 4.0

\section{Introduction}

In the advancement of modern medicine, the demand for biomaterials has increased dramatically since the last decade. Biomaterial can be defined as "Any component or combination of components natural or synthetic in basis, that can be used any time, as a part or whole of a system which treats or replaces any tissue, organ or function of the body and systematically engineered to act together with biological systems to direct medical healing action" [1]. Biomaterials can be classified into four major categories: natural materials (from both plants and animals), polymers, metals and ceramics (including carbons, glass-ceramics, and glasses). Composite materials are also categorized as the fifth class of biomaterials and they are the combination of two or more different classes of materials [2]. Biomaterials have the ability to carry out their function with an appropriate host response. To fulfill the needs of the biomedical community, polymers possess significant characteristics with great diversity of physical and mechanical properties [3, 4]. Biodegradable polymers have been broadly utilized as a part of biomedical applications in terms of their known biocompatibility, bio absorbability and biodegradability. Degradable polymeric biomaterials are now used intensely for short-term prostheses, three dimensional permeable structures as platforms for tissue designing [5], wound healing [6]. and as controlled/managed discharge drug conveyance vehicles [7]. Those polymers are of utmost interest because biomaterials are able to be broken down and emitted or resorbed without subsequent operation or any surgical revision. Biodegradable polymers can be degradable, either enzymatic association or without enzymatically, to deliver biocompatible, nontoxic properties. In developing countries, environmental pollution by synthetic polymers has become a major concern [8]. It was suggested that for many reasons natural biomaterials are the most preferred ones; they are biodegradable, biocompatible, and nontoxic [9]. Economic and environmental aspects are also contributing to the growing interest in natural polymers [10].

\section{Important Properties of Biodegradable Materials/Polymer}

Polymer degradation is a change in the properties - tensile strength, shelf life, durability, structure, size, color etc. of a polymer or polymer based product under the impact of many environmental factors such as air, heat, sunlight or chemicals [11]. A wide variety of natural and synthetic biodegradable polymers have been investigated recently for medical and pharmaceutical applications. In order to be fit for biomedical application three basic properties of biopolymer are: super hydrophobicity [12], adhesion and self-healing [13-15]. So, some very important properties of biodegradable polymer/material that must be fulfilled before going for usage in biomedical treatment are given below:

* Capability of maintaining good mechanical integrity until degraded.

* Capability of controlled rates of degradation [16].

* The material should not arouse a sustained inflammatory or toxic response upon implantation in vivo [3, 4].

* The material should have acceptable shelf life.

* Should possess a degradation time concurring with their function and the degradation time of the material should match the healing or regeneration process. 
* The material should have appropriate mechanical properties as per as application criteria, and any variation in mechanical properties with degradation should be compatible with the healing or regeneration process [17].

* Degradation products should be non-toxic, and easily metabolized and cleared from the body [18].

* The material should have appropriate permeability and processibility for the intended application [1, 19].

* In the case of scaffold-guided tissue engineering, the biodegradable polymer should be process able into a proper shape fitting the defect's site, with a proper micro- nanostructure [20].

* The polymeric materials should be designed into a scaffold structure so as to carry mechanical properties and degradation rate suitable to maintain the spaces required for cell ingrowth and matrix creation, and to bear stresses and loading [21, 22].

\section{Classification of Natural Biodegradable Polymers}

Bio polymer provides an important set of material options for biomaterials and scaffolds in biomedical applications because of its high tensile strength, controllable biodegradability, hemostatic properties, noncytotoxicity; low antigenicity and non-inflammatory characteristics [1].

$>$ Biopolymers fall into two principal categories:

(i) Polymers that are produced by biological systems such as micro-organisms, plants and animals, in short natural products;

(ii) Polymers that are derived from biological materials but are synthesized chemically such as sugars, and natural fats or oils. This also referred to as synthetic natural product based polymers [23, 24].

$>$ Classification of biopolymer according to the monomeric unit and the structure:[25, 26].

- Long polymers -Polynucleotides (i.e. DNA and RNA).

- Short polymers- Polypeptides

- Linear, bonded polymers -Polysaccharides.

$>$ Classification depending on their origin: Kaplan [27].

- Polysaccharides: Xanthan, Dextran, Gellan, Levan, Curd Lan, Polygalactosamine, Cellulose, Pollulan, Elsinan, Yeast Glucans, Starch, Cellulose, Agar, Alginate, Carrageenan, Pectin, Konjan, Various Gums, Chitin, Hyaluronic Acid.

- Proteins: Silk, Collagen/Gelatin, Elastin, Resilin, Adhesive, Polyaminoacid, Soy, Zein, Wheat Gluten, Casein, Serum Albumin.

-Polyesters: Polyhydroxyalkanoates, Polylactic Acid.

- Lipids/Surfactants: Acetoglycerides, Waxes, Emulsion.

- Polyphenols: Lignin, Tannin, Humic Acid.

- Specialty Polymers: Poly Gamma Glutamic Acid, Natural Rubber, Synthetic Polymers from Natural Fats and Oils.

\section{Natural Polymers for Biomedical Application}

Natural polymers are used in medical prosthetic applications like heart valves, cartilage scaffolds, joints, making of artificial skin, blood vessels, urinary catheters, ureteral stents, artificial kidney/Hemodialysis membranes and also for drug delivery. Natural polymers such as nucleic acids and proteins carry and manipulate essential biological information, other polymers like polysaccharides - provide fuel for cell activity and serve as structural elements in living systems [28]. For example, poly (lactic-co-glycolic acid) (PLGA), poly (glycolic acid) (PGA) and poly(lactic acid) (PLA) have been approved by the US Food and Drug Administration for certain medical applications, because their products of degradation are eliminated from the body in the form of $\mathrm{CO}_{2}$ and $\mathrm{H}_{2} \mathrm{O}[29$, 30]. Semipermeable membrane biopolymers (cellulose), with or without use of immunosuppressive drugs having less antigenicity used in artificial kidney for hemodialysis is revolutionary [31]. Natural biodegradable polymeric biomaterials include proteins (Gelatin, albumin, collagen, fibrin, silk etc.) and polysaccharides (Starch, alginate, chitin/chitosan, hyaluronic acid derivatives, etc.) [32-34]. A family of native polyesters - polyhydroxyalkanoates (PHA) has identified as natural biodegradable biomaterials and, recently, ivy nanoparticles (macromolecular compositions of nanospherical proteins) and sundew adhesives (natural polysaccharide-based hydrogels) have garnered more attention for their potential use as nano-carriers in drug delivery and for their ability to create effective nanocomposite adhesives respectively [35-37].

\section{Alginate}

Alginate is of interest as a potential biopolymer film or coating component because of its unique colloidal properties, which include thickening, stabilizing, suspending, film forming, gel producing, and emulsion stabilizing [38]. In molecular terms, it is a family of unbranched binary copolymers of $\beta$-D-mannuronic acid and $\alpha$-L-guluronic acid residues of widely varying composition and sequential structure [39]. Typically, the building blocks are composed of three different forms of polymer segments: consecutive $\mathrm{G}$ residues, $\mathrm{M}$ residues and al MG residues. The most useful and unique property of alginates is their ability to react with metal cations, specifically calcium ions, to produce strong gels or insoluble polymers [40]. 


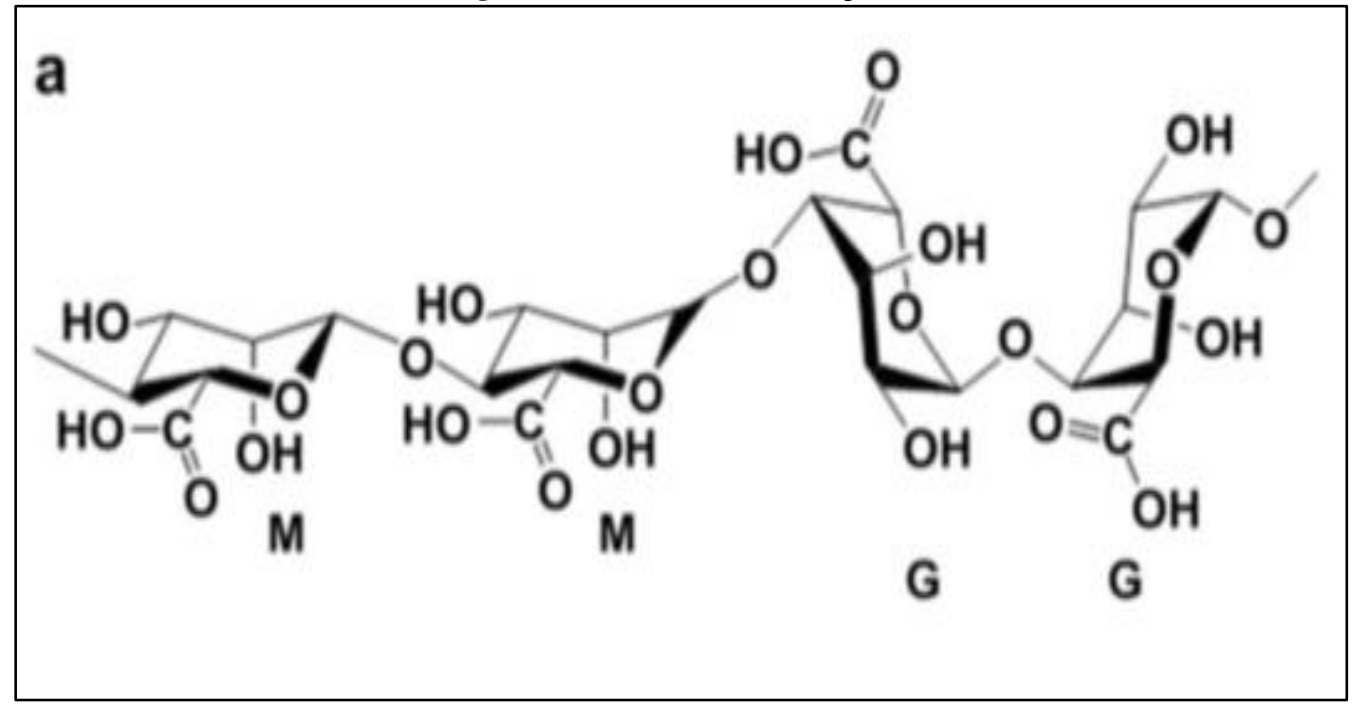

Alginate is now rapidly used as the supporting matrix or delivery system for tissue repair and regeneration [41]. Due to its outstanding properties in terms of biocompatibility, biodegradability, non-antigenicity and chelating ability, alginate has been widely used in biomedical applications including tissue engineering, drug delivery and for preventing gastric reflux $[42,43]$. The primary drawbacks of alginate are its comprehensive lack of strong mechanical properties, poor cell adhesion, and its lack of degradability in mammals [44]. However, by combining alginate with other biomaterials such as chitosan, agar and by partially oxidizing alginate with molecules like sodium periodate, it is now possible to enhance its mechanical properties and degradability, conferring significant promise on alginate-based biomaterials [45]. One study showed that, creating FCA/COS blended film, resulted in a scaffold with superior physical, mechanical, and biologic properties, improved cell adhesion and proliferation, ECM compatibility, improved porosity and water uptake that could be used for skin tissue-engineering application [46]. Sodium alginate - due to its good gel forming ability, biocompatibility, and relatively simple amendments-has also been studied for its use in bone regeneration and myocardial tissue regeneration [47]. Sodium alginate has one of the largest applications in the field of wound healing, not only its excellent bioresorbable and biocompatible nature, but also because of its ease of gelation and its physical cross-linking abilities, chemical cross-linking formation ability $[37,47,48]$.Another study formulated combination of 75: $25 \mathrm{Na}$ alginate: Gelatin and loaded it with Ag sulfadiazine (a metal antimicrobial) for application as wounds healing film in freeze-dried wafers. Sodium alginate gel was used as the main biomaterial primarily because it creates a moist environment that promotes healing, exchange between ions in the wound exudate and the dressing [37, 49].

Figure-2. Fabricating techniques of alginate-based sponge by Freeze-drying method

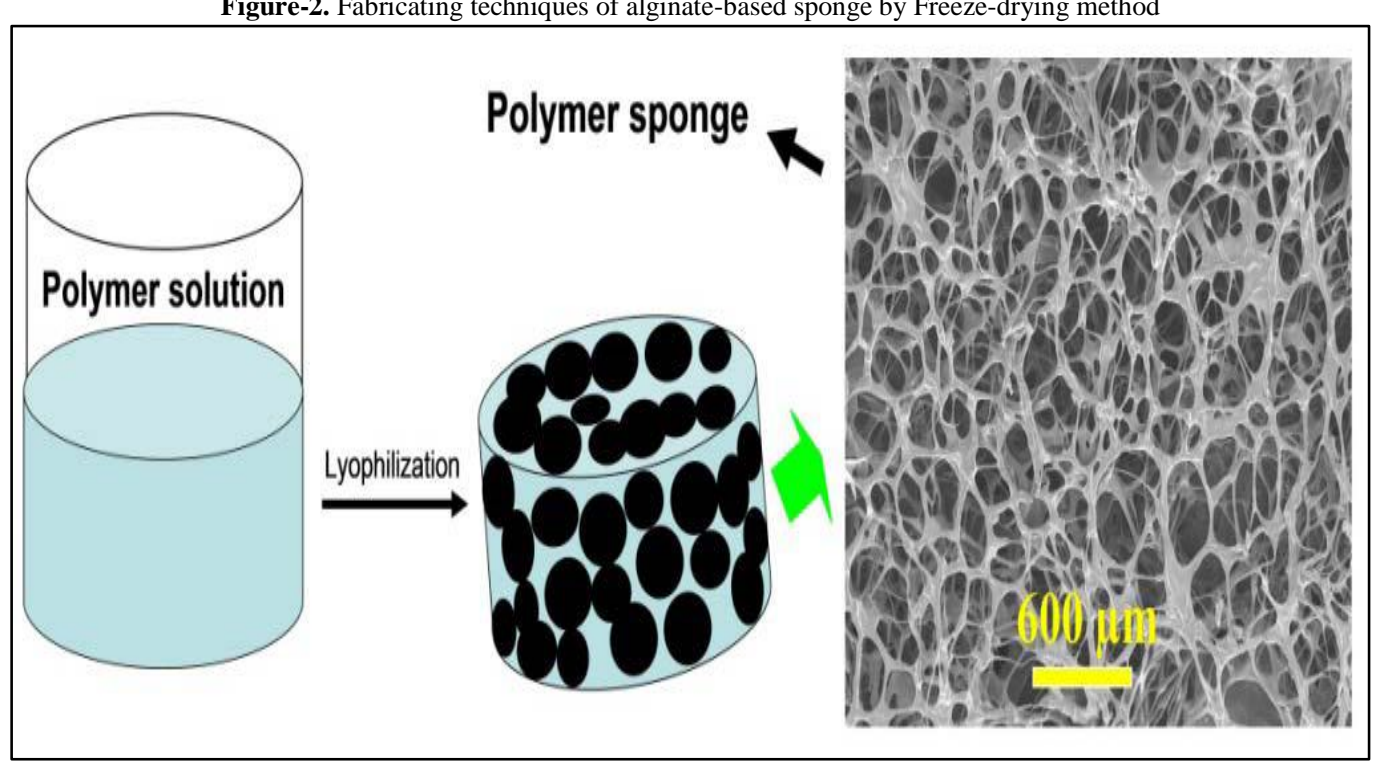

Alginate can be easily formulated into porous scaffolding matrices of various forms (spheres, sponges, foams, fibers and rods) for cell culture and response for regenerative medicine applications. It has been suggested that certain alginate dressings (e.g. Kaltostat $\left.{ }^{\circledR}\right)$ can enhance wound healing by stimulating monocytes to produce elevated levels of cytokines such as interleukin- 6 and tumor necrosis factor- $\alpha$ [50]. Production of cytokines at wound sites results in pro-inflammatory factors that are advantageous to wound healing [41]. There have been also numerous studies involving the use of injectable alginate-based scaffolds for bone regeneration [51-54]. However, current alginate is still unable to meet all the design parameters simultaneously (e.g. degradation, bioactivities or 
mechanical properties).In further studies, efforts should be made to improve alginate and thus, support the development of more natural and functional tissues [41].

\section{Collagen}

Collagen is an enzymatically degradable polymer which accounts for about $20-30 \%$ of total mammalian body proteins [55]. In human body, more than 28 different types of collagen have been identified. Among them the most common type of collagen: Type I-IV [56]. Length and width of collagen is about 300nm \& 15A, respectively, and has an approximate molecular weight of $300 \mathrm{kDa}$ [57]. Collagen is a hydrophilic protein because of the greater content of acidic, basic and hydroxylated amino acid residues than lipophilic residues. Shape is similar to rod like $\&$ it has a characteristic triple-helix structure.

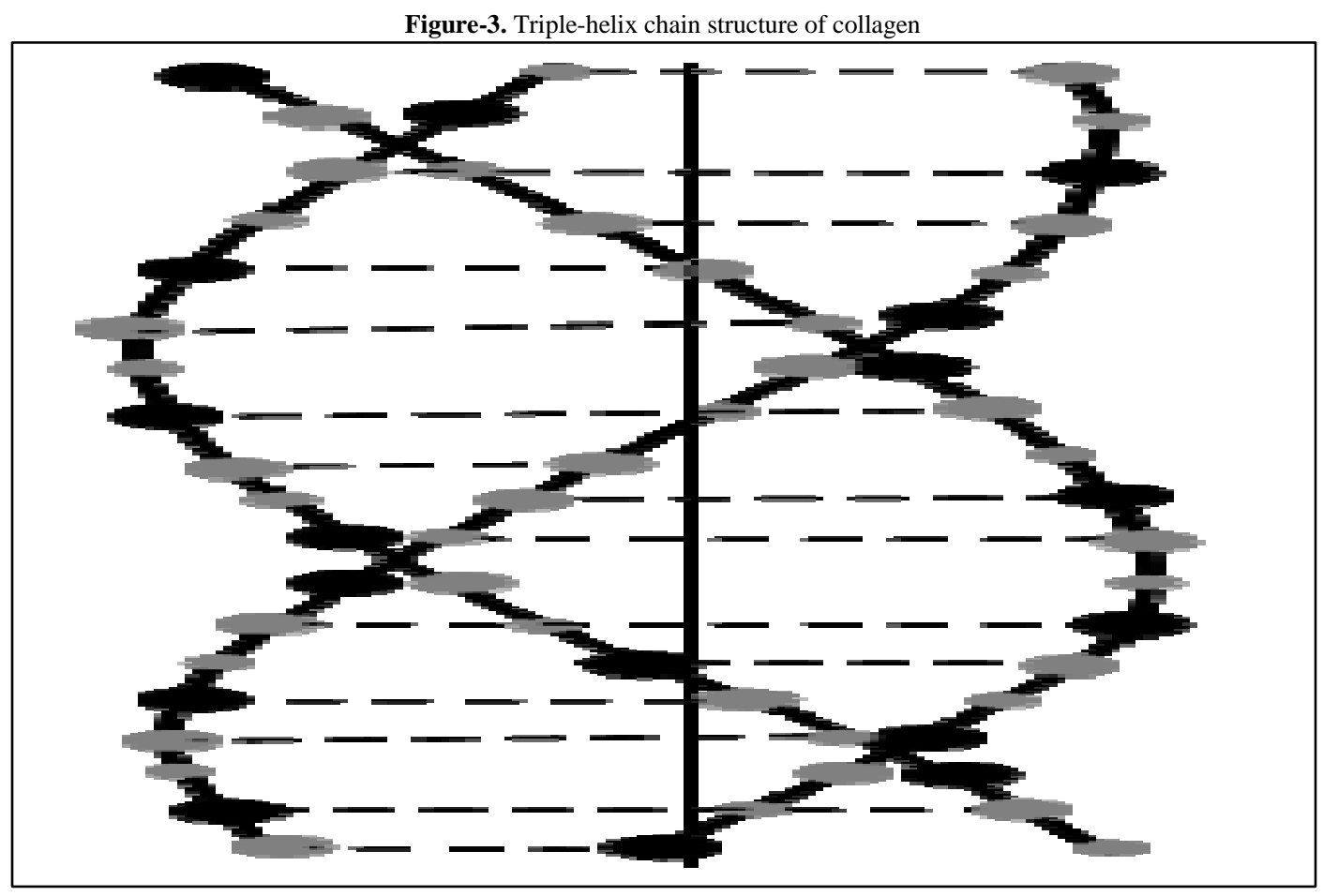

Recognitions of its biodegradability, low antigenicity, cell-binding properties and good mechanical strength, collagen has been extensively considered for biomedical treatment especially in tissue engineering, bone regeneration $[57,58]$. But this excellent high biodegradable property has become a limitation for using as biomedical polymer [59]. To modify its high degradation rate, several efforts have been made for example by addition of mineral crystals [60], natural polymer (i.e. elastin) [61], Hyaluronic acid [62] or synthetic polymers (i.e. methacrylate derivatives [63,64], or by applying various crosslinking procedures [65]. In preserving the biological and structural integrity of the Extracellular matrix, collagen plays a critical role. Collagen is process able in high soluble acidic aqueous solutions .This unique property allows for the fabrication of collagen sponges, tubes [66], sheets [67], powders, and injectables. Injectable collagen is widely used for the growth or buildup of dermal tissue for cosmetic reasons [24]. From the last centuries, collagen has been used as a suture material, for example, catgut, is now being used in surgical purpose, but the limitation is infection rates and inflammation in sutures increases due to collagen, that's why synthetic sutures are much more commonly used today. Collagen products are frequently being used for the attraction of fibroblasts during wound repair, fracture healing, drug delivery systems [68-70]. One study showed that collagen based hydrogel was used as gene delivery carriers. For promoting bone formation collagen film and matrix have been also used as gene delivery carriers [57]. Nanoparticle based collagen are have also been used for therapeutic agents and this are nano based collagen are thermally very stable [71]. Collagen as a biomaterial has already seen significant use, so notable steps should be carried out to come up with the limitations so that outstanding impact of collagen as biomaterial will be far better than before.

\section{Carrageenan}

Carrageenan is derived from the cell wall and intercellular matrix of the seaweed plant tissue of the class Rhodophyceae. It is high viscosifying polysaccharide with $15-40 \%$ ester-sulfate content. It is formed by alternate units of D-galactose and 3, 6 anhydro-galactose (3.6-AG) joined by $\alpha-1,3$ and $\beta-1,4$-glycosidic linkage [72]. Structure of carrageenan's are different from agars is that the B units in carrageenan are in the D form, whereas they are in the L form in agar's [73]. Seaweeds of different species and sources produce different types of carrageenan such as kappa, iota and lambda. Some species of seaweed may produce a mixed type carrageenan such as kappa/iota, kappa/lambda or iota/ lambda [72]. 


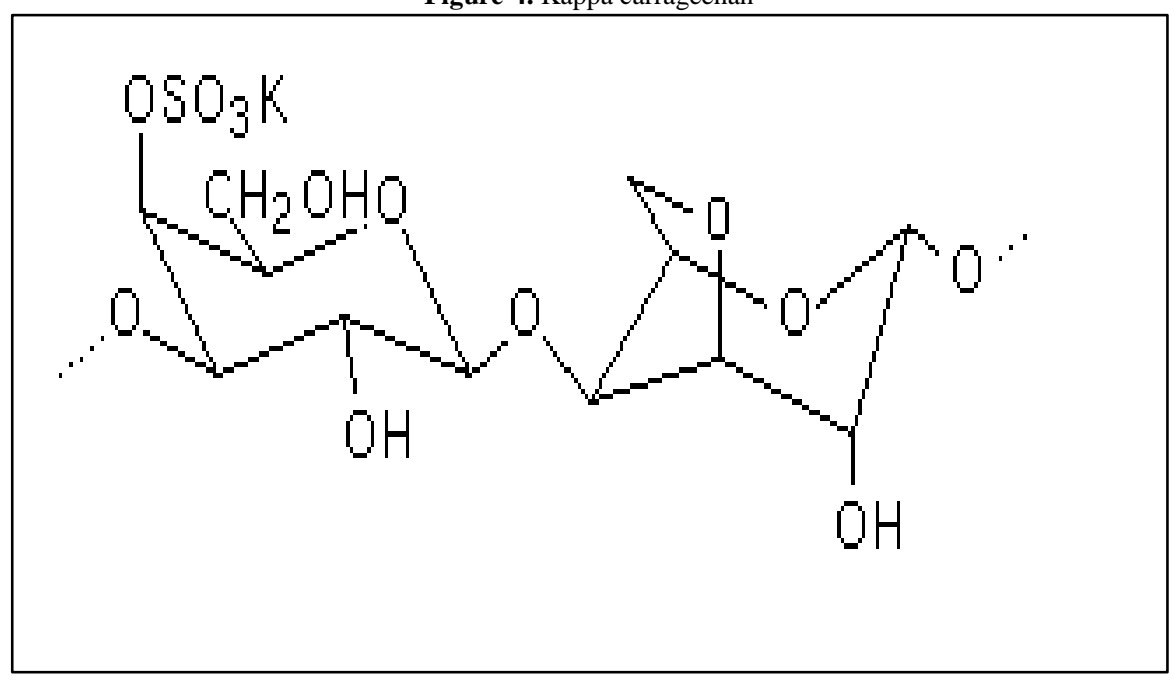

Figure-5. Iota carrageenan

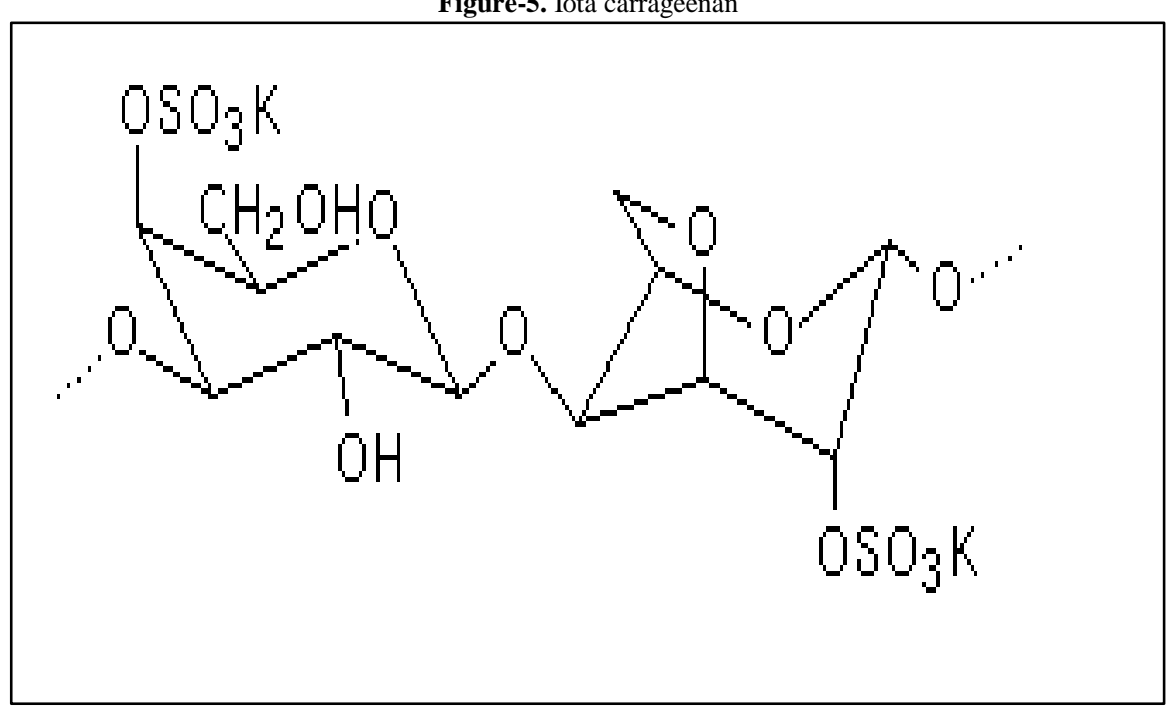

Figure-6. Lambda carrageenan

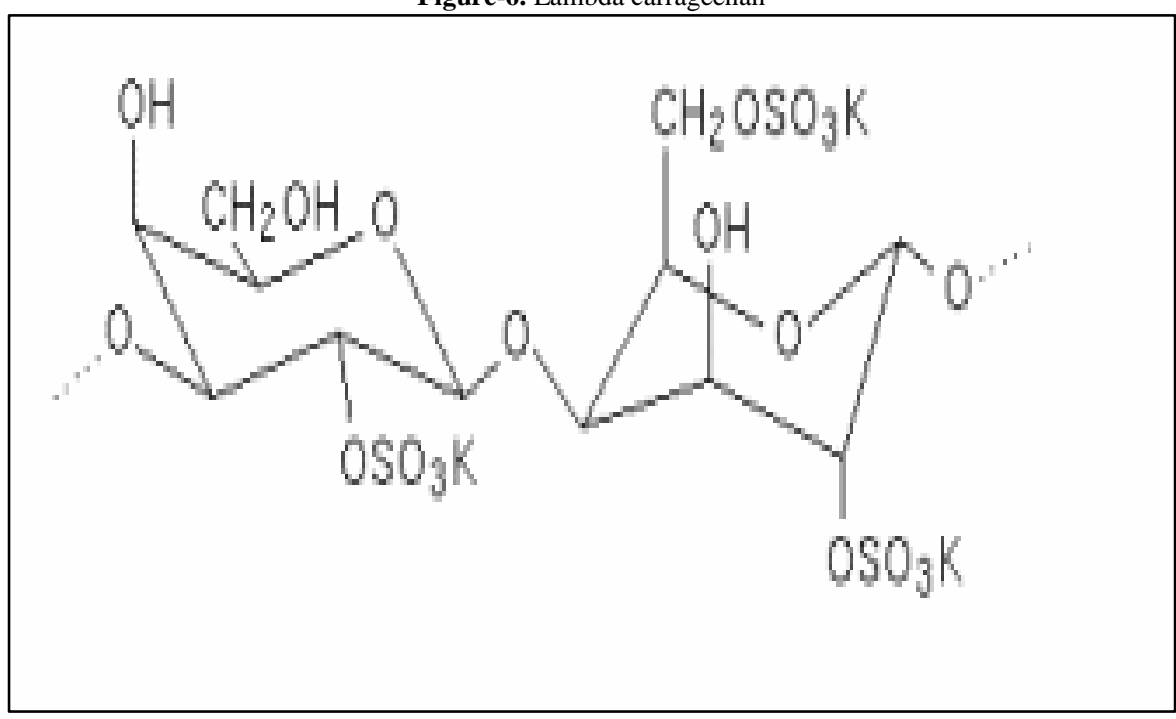

Carrageenan has a unique property to form a variety of gel textures at room temperature: rigid or elastic, clear or turbid, tough or tender, heat stable or thermally reversible, low or high melting/gelling temperatures [72]. Carrageenan is a selective inhibitor of several enveloped viruses, such as human pathogens as human immunodeficiency virus, herpes simplex virus (HSV), human cytomegalovirus, human rhinoviruses and others [74, 75]. A study showed Carrageenan based bionanocomposites which has been used as drug delivery tool [76]. It can be used in both topical bases and suppository bases. It has excellent thickening and binding property for which carrageenan is being used in dentifrices and prevents solid-liquid separation $[25,77]$. 


\section{Agar}

Discovered in Japan, in 1658 by Mino Tarōzaemon, Agar-agar is a hydrocolloid extracted from red seaweeds belonging to the Rhodophyceae class [72]. Its a linear polymer combination of two separate polysaccharide: agarose and agaropectin, where agarose making up about $70 \%$ of the combination. Xylose has been found in some agars.

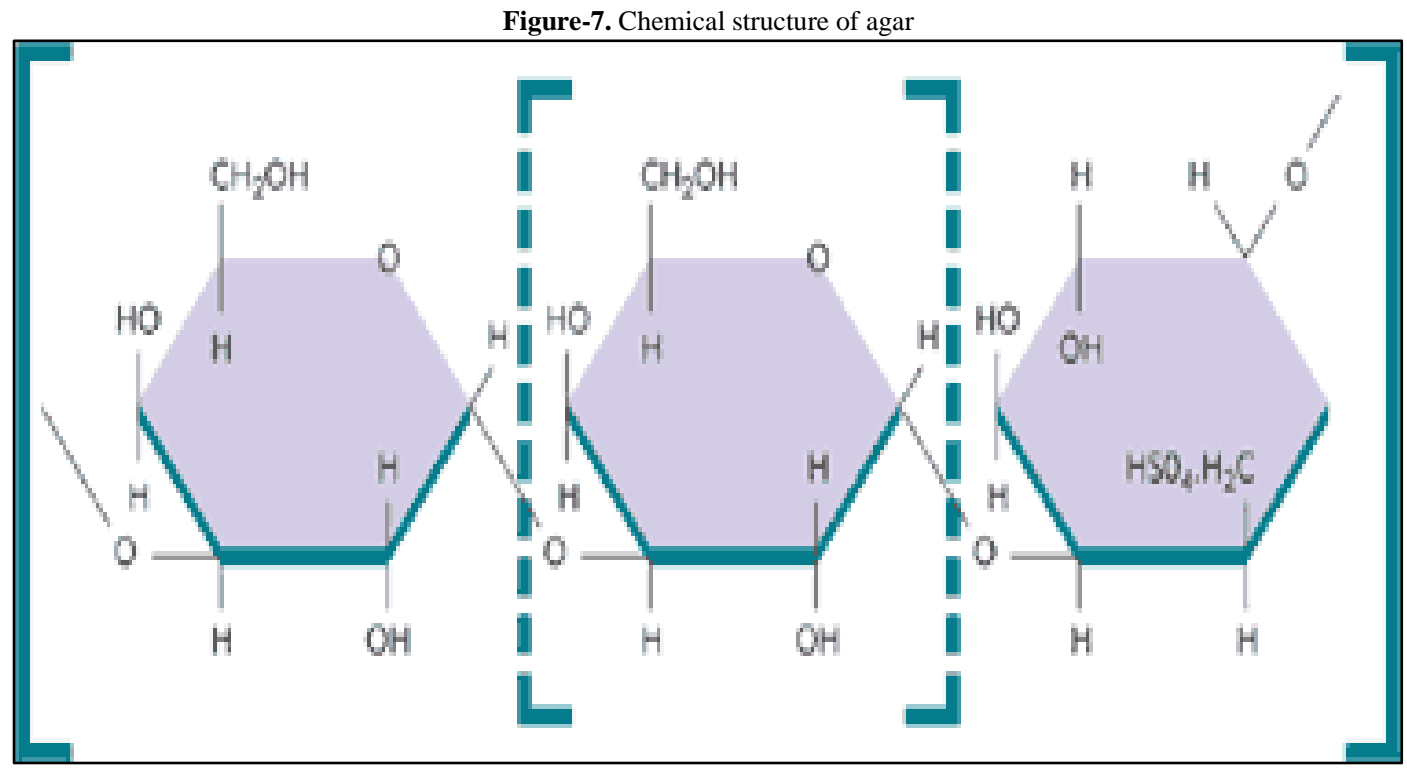

Its high gel strength at low concentrations, low viscosity in solution, high transparency in solution, thermoreversible gel and sharp melting/setting temperatures makes it suitable for usage in biomedical treatment [78]. Agar is used as an impression material in dentistry, as a medium to precisely orient the tissue specimen and secure it by agar pre-embedding (especially useful for small endoscopy biopsy specimens) for histopathology processing [79], to make salt bridges and gel plugs for use in electrochemistry , as a substrate for precipitin reactions in immunology [80]. Agar based hydrogels are used for manufacturing contact lenses, hygiene products, tissue engineering scaffolds, drug delivery systems and wound dressings [81]. In addition, thanking to its biodegradability, agar based hydrogel blended with gelatin \& collagen has also been studied for wound healing, drug delivery and tissue engineering etc [82]. More studies on agar is still going on continuously to widespread its usage as biomedical polymer.

\section{Gelatin}

Gelatin is a natural biopolymer derived from controlled denature of the fibrous insoluble protein, collagen. It is obtained through alkaline, acid, or enzymatic hydrolysis [83]. Cattle bones, hides, pig skins, and fish are the principle commercial sources of gelatin [25]. It is a relatively low-cost polymer and it is widely available. Gelatin is an edible protein where all essential amino acids except tryptophan are available [84]. Gelatin has excellent biodegradability, biocompatibility and surface-active properties in physiological environments for which it has been used in medical and pharmaceutical fields, technical applications, microencapsulate aromas, vitamins, and sweeteners [85]. From total gelatin manufactured in worldwide is $65 \%$ used in foods, $20 \%$ in photographic applications, $10 \%$ in pharmaceutical products, and 5\% in other specialized and industrial applications [8]. Gelatin has excellent film forming capability that is transparent, flexible, impermeable to oxygen and water-resistant [86]. In the biomedical field, gelatin is being used as a matrix for implants, to develop specific drug-release profiles as micro particles, nanoparticles, fibers, and hydrogels and as stabilizers in vaccines such as measles, mumps, and rubella [87]. Furthermore, it also has grater use as scaffold for tissue engineering, as a wound dressing, and as absorbent pad, adhesive for surgical use $[69,88]$. Foox et al showed that for drug delivery to the brain, gelatin micro particles served as vehicles for cell amplification [89]. Ozkizilcik A et al, invented a new method for the production of gelatin micro particles for controlled high protein and drug-loading efficiencies [90]. Cohen B discovered novel gelatin/alginate soft tissue adhesives loaded with drugs for wound closing applications [91]. Gelatin can be easily cross-linked by a variety of cross-linking agents to form hydrogels. In another study, Malafaya et al. designed [92] several gelatin-based carriers for biomedical applications, for example, Gelfilm ${ }^{\circledR}$, a gelatin film used in neurosurgery and thoracic and ocular surgery; Gelfoam ${ }^{\circledR}$, a gelatin sponge for hemostatic applications. But its usable practice is heavily limited by its poor mechanical properties [93]. So, in future more research needs to be investigated on gelatin to have noticeable impact for use as a biomaterial.

\section{Starch}

Starch is the most abundant and cheap polysaccharide reserve material constituent of photosynthetic tissues and of many storage organs in plants. It is found in corn, rice, maize and potatoes etc. Granule sizes, amylose/amylopectin ratio, mineral contents, and amount of phosphorous and phospholipid contents may vary from plant to plant and this effects on starch physical and mechanical properties. Its chemical structure consists of a 
mixture of two polysaccharide, amylose and amylopectin. Amylose is a linear poly(1,4- $\alpha$-D-glucopyranose) which consists of about $30 \%$ and amylopectin is branched poly(1,4- $\beta$-D-glucopyranose) with branches of $(1,6-\alpha-$ Dglucopyranose) consists of about $70 \%[94,95]$.

Figure-8. Structure of starch

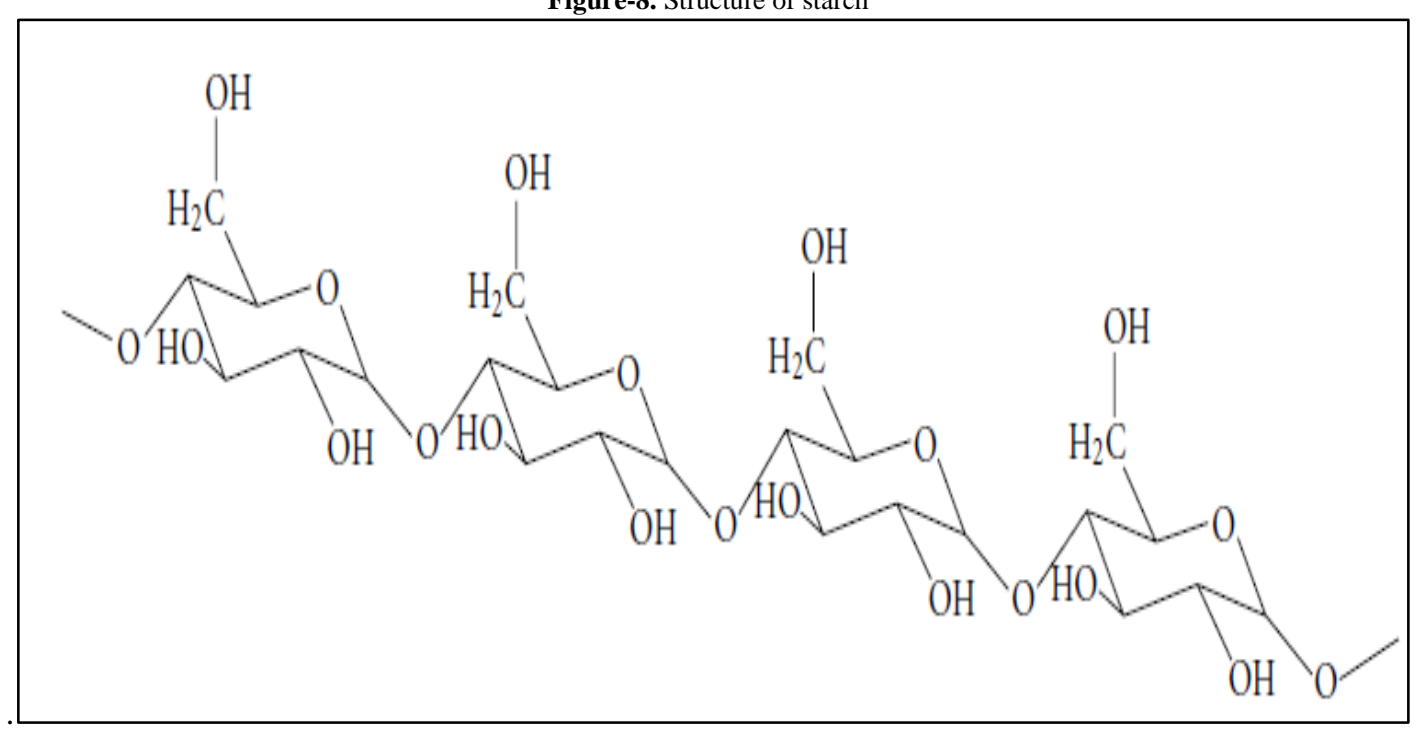

There are three types of crystallinity in starch. They are the 'A' type, 'B' type, 'C' type .Starch is insoluble in cold water, but it is very hygroscopic and binds water reversibly. As starch is renewable, biodegradable, inexpensive, so it is vastly useful in tissue engineering, delivery of biologically active compounds, bone replacement implants, bone cements to drug delivery systems, cancer therapy, nasal administration of insulin, antibiotics, vaccines and tissue scaffolds [96] etc. Being established and widely used biodegradable polymer, it have been also proposed as bone engineered scaffolds, bone cements and micro particles or hydrogels for controlled drug delivery [97, 98]. A number of studies by Gomes and co-workers have been carried out to discover starch-based scaffolds for bone and cartilage tissue engineering, and also analyzed their functional, mechanical properties, blend component, material processing technique [99, 100]. Among its drug delivery application, its hydrogel form can efficiently enclose drugs and protects them from undesirable conditions in the human body [101]. Development of the polymer nanocomposites is one of the latest revolutionary approach. In a study by Mahdieh et al, they synthesized a nanocomposite biomaterial where nano-structured forsterite and vitamin $\mathrm{E}$ incorporated as the ceramic reinforcing phase and thermal stabilizer and blend of thermoplastic starch and ethylene vinyl alcohol incorporated as the polymer matrix [102]. Starch is noncytotoxic, biocompatible, exhibits a high Young's modulus with low levels of elongation at break, relatively easy to modify chemically, and it has the ability to replace expensive synthetic polymers during the fabrication of composite biopolymers [103]. By blending starch with thermoplastic polymers, these biopolymers shows improved thermal stability, mechanical properties and melt process ability. Some studies showed blends of starch with ethylene vinyl alcohol (SEVA-C), cellulose acetate (SCA), polycaprolactone (SPCL) and poly(lactic acid) (SPLA) exposed the potentiality of starch-based biopolymers as scaffolds in tissue engineering. [104, 105]. Further research should be emphasized on improving more properties, thus revolutionizing the use of this material as biomedical application.

\section{Cellulose}

Cellulose is the most renewable, abundant polymer consisting of unbranched chain $\beta(1 \rightarrow 4)$ linked $D$ glucopyranosyl units (anhydroglucose unit). Cellulose is a very highly crystalline, high molecular weight polymer, which is infusible and insoluble. Its primary source is the lignocellulose material in of plants and other sources are natural fiber like cotton, linen; algae, bacteria biosynthesis, and chemosynthesis [106]. 


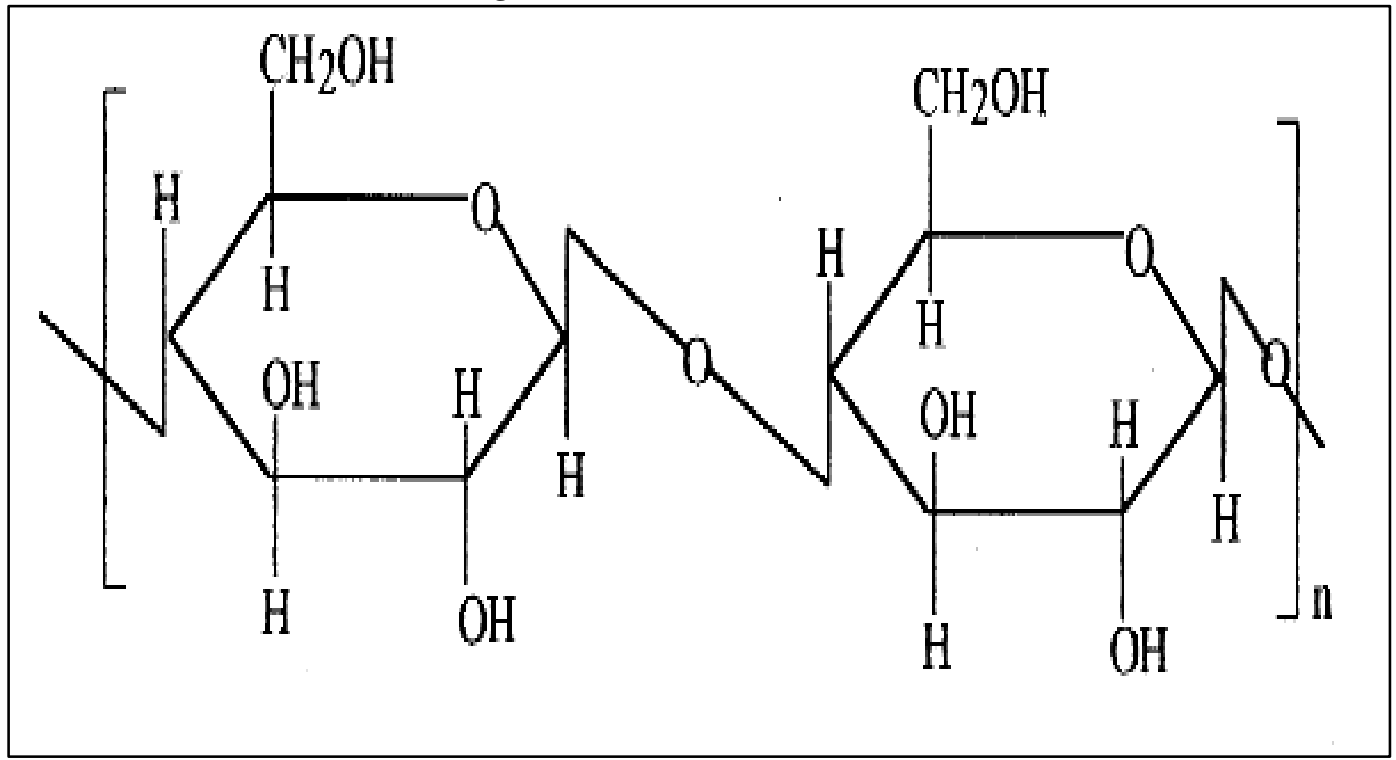

Due to availability, environment friendly, biocompatible behavior, it has widespread application in biomedical application; most commonly natural fiber i.e. cotton, linen and regenerated fiber i.e. lyocell, rayon, viscose [107]. Several researchers investigated the use of cellulose for different biomedical applications, including wound healing and engineering of various tissues, such as blood vessel, cornea, cartilage and bone [108-110]. Wan et al, Hong et al developed bacterial cellulose-based nanocomposites incorporated by nanoparticles into $\mathrm{BC}$ matrices in order to promote mechanical, technical properties for biomedical application [111,112]. For its excellent biocompatibility, good mechanical properties usage of bacterial cellulose for devices as controlled drug delivery i.e.in solid tablets, scaffolds for regenerative medicine, wound dressing is on the verge now-a-days.

\section{Chitosan}

Chitosan is a linear nitrogen-containing polysaccharide that is constituted of $\beta-(-(1,4)$-linked $\mathrm{N}$-acetylglucosamine units $[113,114]$. Chitosan are regarded as the second most abundant natural polymer after cellulose found in the exoskeletons of crustacean and insects as well as some bacterial and fungal cell walls. It is extremely insoluble in most solvents, but it can be solubilized in acidic solution [115].

Figure-10. Chemical structure of chitosan

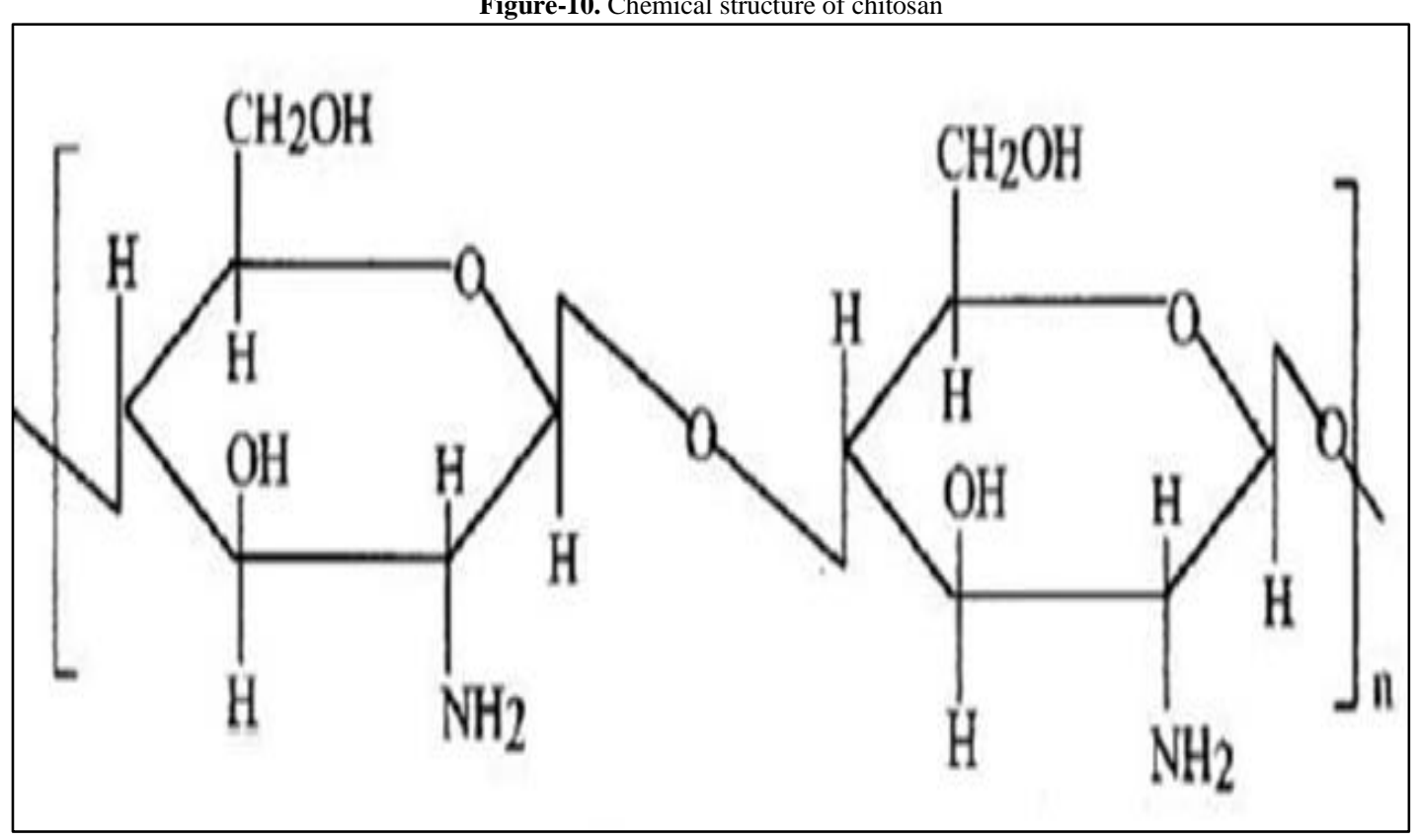

Chitosan has some functional groups that allow for graft modification which helps to improve its solubility and consequently widen its applications [116]. Chitosan is susceptible to enzymatic degradation by non-specific enzymes from a variety of sources, such as lysozymes, chitinases, cellulases or hemicellulases, proteases, lipases and $\beta-1,3-$ 1,4-glucanases [117]. There are four chronological steps by which chitosan can be processed from crustacean shells. They are namely, deproteination, demineralization, discoloration, and deacetylation. It is an attractive biomaterial for different applications in the biomedical field. Chitosan exhibit multiple bioactivities, for example, low toxicity, 
biocompatibility, biodegradable, antimicrobial properties that favours both soft and hard tissue regeneration, wound dressing materials, drug carriers etc. [118]. Chitosan can protect DNA, improve drug absorption, increase the expression period of genes and stabilization of drug components to increase drug targeting. Chitosan can be processed into porous matrices for scaffold construction because it can influence cell behavior and tissue formation of the engineered construct [119]. Incorporating with anticancer agents, chitosan can execute better anticancer effects with gradual release of free drug in the cancer tissues [120]. Chitosan can also accomplish better antitumor effects by secretion of interleukin (IL)-1 and 2, which results in the maturation of cytolytic T-lymphocytes [121]. Functional capabilities of chitosan exhibit a bactericidal effect on both Gram-negative and Gram-positive bacteria and opened an array for biomedical applications, including tissue engineering, drug delivery, wound healing, and temporary implants. In a recent research by Yang et al, chitosan based nanoparticles with paclitaxel (a chemotherapy drug), by aggregation of intracellular nanoparticle, successfully discovered trapping ability for the treatment of lung cancer and tumor [122]. In another study by Wang, L et al, for good drug release efficiency, good stabilization, low outbreak, and steady release of insulin ,insulin-based chitosan nanoparticles have been synthesized through polymer crosslinking [123]. Chitosan can bind DNA and prevent DNA from being degraded by nucleases and high level of chitosan nanoparticles loaded with interleukine-2 plasmids have been assessed as milestone for gene-based immune therapy [124]. Overall, the unique chemical properties of chitosan have recently allowed it to be studied for biomedical application. Elaborate research and animal experiments on chitosan-based high-tech products should be carried on more in future for the benefit of humankind.

\section{Fibrin}

Fibrin is a fibrinogen-derivative biopolymer composed of fibronectin and the fibrinogen molecule is composed of three polypeptide chains, named $\alpha, \beta$, and $\square$, which are joined together by six disulfide bridges. Fibrin is natural, highly available, implantable, inexpensive, and easy to use. It is a critical blood component involved for natural blood-clotting process, surgical adhesive including neurosurgery and plastic and reconstructive surgery, tissue engineering, drug delivery, cell encapsulation enhancing cell adhesion and proliferation due to its biocompatibility, biodegradability and injectability and has a wide range of application for biomedical purpose [125, 126]. Fibrin has been utilized as a scaffold for the regeneration of numerous tissues, such as adipose tissue, bone, cardiac tissue, cartilage, , liver, nervous, ocular, skin, tendon, and ligament tissues, muscle tissue, nervous tissue, ocular tissue, respiratory tissue and vascular tissue as well as a carrier vehicle for bioactive molecules (drugs, antibiotics, or chemotherapy agents) [127-129]. Several researchers have demonstrated that clinical application of fibrin significantly improved the healing of chronic periodontitis [130]. Attempts have been carried out to develop microspheres, nanospheres fibrin-based drug-delivery carriers and tissue-engineered scaffolds to enhance its biomedical value.

\section{Hyaluronic Acid}

Discovered in 1934, Hyaluronic acid is a linear anionic polysaccharide composed of the repeating unit of $\mathrm{N}$ acetyl-D-glucosamine and glucuronic acid. It is isolated from extracellular matrix of skin, cockscomb, cartilage, vitreous humor, rooster combs, umbilical cord, synovial fluid and from other body tissue [131]. HA forms highly viscous solutions, very hydrophilic, flexible, high capacity of water retention, and influences several cellular functions such as migration, adhesion, and proliferation. These factors have

Figure-11. Chemical structure of hyaluronic acid

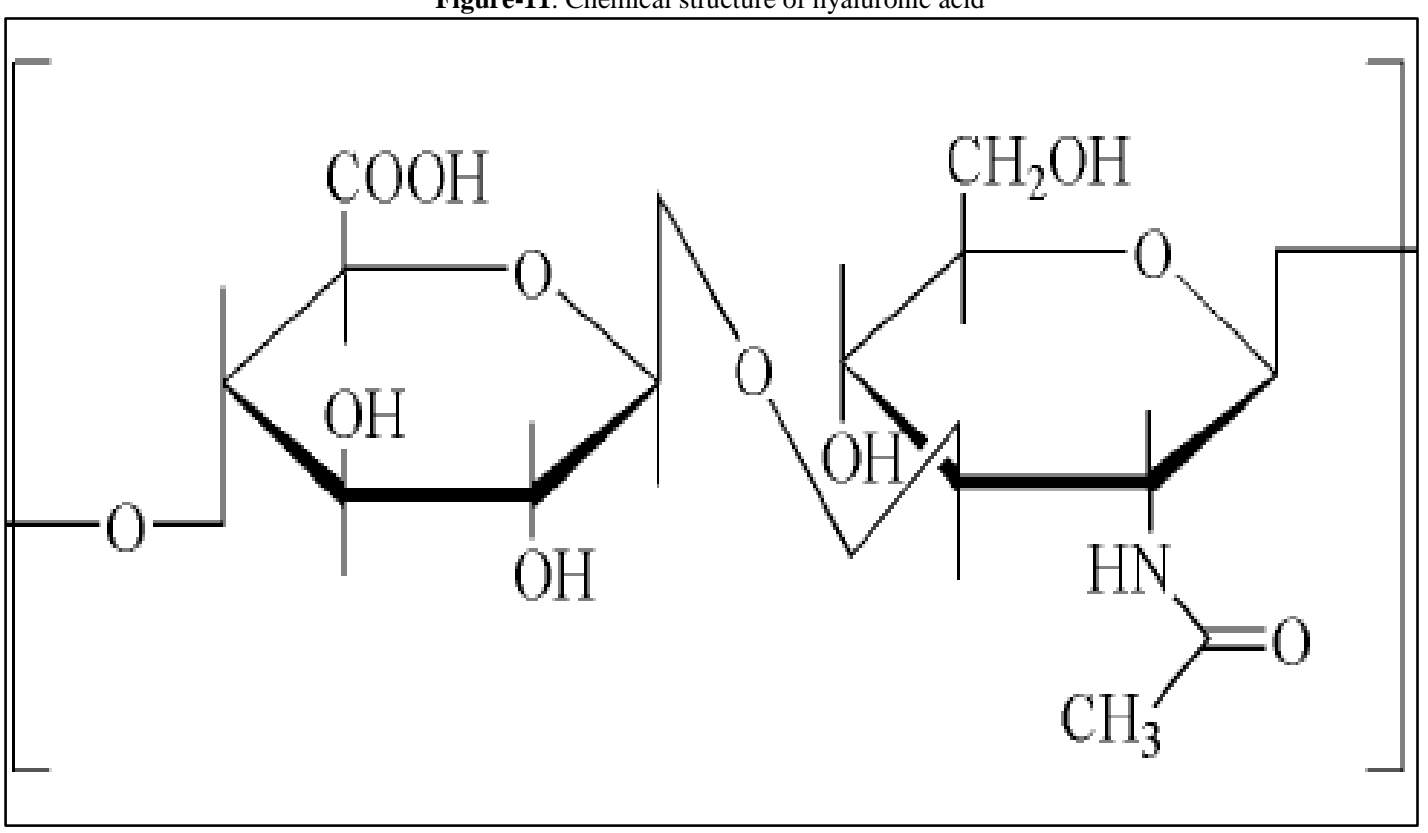

made it a promising material for tissue repair, scaffolds for wound healing and tissue engineering, as well as ophthalmic surgery, arthritis treatment, and as a component in implant materials, lubricating fluid in joints, facial 
wrinkles and folds of the skin as a regulator in the lymphatic system both in vivo and in vitro [132, 133]. HA promotes cell migration and differentiation, making it vital for tissue repair, tissue engineering. Modification of HA into various porous and 3D structures is currently utilized as a carrier vehicle for drug delivery [125]. HA based nanoparticles have also shown aptitude as a delivery vehicle to deliver chemotherapeutics, antibiotics [134]. HAbased scaffolds can be engineered to possess controllable degradation properties to achieve long-term stability and increased mechanical strength, and to regulate the release kinetics of bioactive agents. Various strategies have been adopted including photocrosslinked and covalent cross-linked HA scaffolds, HA-modified poly (D, L-lactic acid-coglycolic acid) (PLGA) scaffolds were successful in inducing cartilage tissue formation in tissue engineering [135]. HA is also an ideal wound healing biomaterial to reduce pain and enhance joint mobility in the body of patients [136].

\section{Conclusion}

The purpose of this paper is to explore and constitute the concepts that a biomaterial can change with the radically new types of substance that we are using, in many new ways, in medical technology so that it will attract the attention of specialists in the study of natural based biopolymers. Natural polymers, particularly in the form of microspheres, nanoshperes has opened the array for clinical applications in various forms, such as wound healing materials, temporary prostheses, scaffolds for tissue engineering and controlled drug delivery devices because of its low toxicity, biodegradability, stability and renewable nature. Numerous challenges still exist today across biomaterials, so there has been an exponential need to focus on more research and interest into making such a technology into reality. There is a need to develop a well-tested production path for producing the biomaterials from the natural polymer. It is hoped that this will stimulate constructive debate about the biomaterials of today and of the future [137].

\section{References}

[1] Yang and Bochu, W., 2009. "Biodegradation of silk biomaterials." Int. J. Mol. Sci., vol. 10, pp. 1514-1524.

[2] Ratner, B. D., Hoffmann, A. S., Schoen, F. J., and Lemons, J. C., 2004. Biomaterials science: An introduction to materials in medicine. 2nd ed. London, UK: Elsevier Academic Press.

[3] Williams, D. F., 1999. Ed, The Williams dictionary of biomaterials. Liverpool: Liverpool University Press.

[4] Williams, D. F., 2009. "Biomaterials." vol. 30, pp. 5897-5909.

[5] Rosellini, E., Cristallini, C., Barbani, N., Vozzi, G., and Giusti, P., 2009. "Preparation and characterization of alginate/gelatin blend films for cardiac tissue engineering." Journal of Biomedical MaterialsResearch Part A 91A, p. 447.

[6] Thu, H. E., Zulfakar, M. H., and Ng, S. F., 2012. "Alginate based bilayer hydrocolloid films as potential slow-release modern wound dressing." International Journal of Pharmaceutics, vol. 434, p. 375.

[7] Vasanthi, K., 2017. "Biodegradable polymers - a review." vol. 3, p. 7.

[8] Babak, G. and Hadi, A. "Biodegradable polymers, chapter 6."

[9] Ivanova, N., 2012. "Biomaterials: Silk as a natural biomaterial." ISRN Materials Science, vol. 2012, p. 20.

[10] Leja, K. and Lewandowice, G., 2010. "Polymer biodegradation and biodegradable polymers-review [J]." Polish Journal of Environmental Studies, vol. 19, pp. 255-266.

[11] Ashwin Kumar, A., Karthick, K., and Arumugam, K. P., 2011. "Properties of biodegradable polymers and degradation for sustainable development." Int. J. of Chemical Engineering and Applications, vol. 2,

[12] Bassas-Galia, M., Follonier, S., Pusnik, M., and Zinn, M., 2016. "2-natural polymers: A source of inspiration, bioresorbable polymers for biomedical applications." Perale G Hilborn J. Eds, vol. 2016, pp. 31-64.

[13] Mao, C., Liang, C., Luo, W., Bao, J., and Shen, J., 2009. "Preparation of lotus-leaf-like polystyrene microand nanostructure films and its blood compatibility." Journal of Materials Chemistry, vol. 19, pp. 90259029.

[14] Thakur, V. K. and Kessler, M. R., 2015. "Self-healing polymer nanocomposite materials: A review." Polymer, vol. 69, pp. 369-383.

[15] Ibrahim, I. D., Sadiku, E. R., Jamiru, T., Hamam, A., and Kupolati, W. K., 2017. "Applications of polymers in the biomedical field." Juniper Publishers, vol. 4,

[16] Buddy Ratner, D., 2004. Biomaterials science: an introduction to materials in medicine. 2nd ed. San Diego, Calif: Elsevier Academic Press.

[17] Schmitt, E. E. and Polistina, R. A., 1967. "Uspto, ed United States." Patent, vol. 3, p. 33.

[18] Schmitt, E. E. and Polistina, R. A., 1963. "Uspto, ed. United States." Patent, vol. 3, p. 158.

[19] Lloyd, A. W., 2002. "Interfacial bioengineering to enhance surface biocompatibility." Med. Device Technol., vol. 13, pp. 18-21.

[20] Puppi, D., Chiellini, F., Piras, A. M., and Chiellini, E., 2010. "Polymeric materials for bone and cartilage repair." Prog Polym Sci., vol. 35, pp. 403-440.

[21] Hutmacher, D. W., 2000. "Scaffolds in tissue engineering bone and cartilage." Biomaterials, vol. 21, pp. 2529-2543.

[22] Nair, L. S. and Laurencin, C. T., 2007. "Biodegradable polymers as biomaterials." Prog Polym Sci., vol. 32, pp. 762-798. 
[23] Nakanishi, K., 1999. "An historical perspective of natural products chemistry." In Comprehensive Natural Products Chemistry, vol. 8, pp. 21-48.

[24] Oladeji, O. I. and Lasisi, E., 2012. "Umoru and sunday aribo, Natural products: Aminefield of biomaterials, international scholarly research network." ISRN Materials Science, vol. 2012,

[25] Preeti, Y., Harsh, Y., Veena Gowri, S., Gaurav, S., and Gaurav, D., 2015. "Biomedical biopolymers, their origin and evolution in biomedical sciences: A systematic review." Journal of Clinical and Diagnostic Research, vol. 9, pp. ZE21-ZE25.

[26] Pakawadee, K., 2012. "Fermentation of sweet sorghum into added value biopolymer of polyhydroxyalkanoates (phas). In: Casparus johannes reinhard verbeek editor. Products and applications of biopolymers." Croatia: Intech, pp. 41-60.

[27] Kaplan, D. L., 1994. Naturally occurring biodegradable polymers' g swift and r narayan (eds). Polymer. Systems-synthesis and utility. New York: Hanser Publishing.

[28] Reis, R. L., 2008. Natural-based polymers for biomedical applications. Abinghton, UK: Woodhead Publishing Limited.

[29] Liu, Slamovich, E. B., and Webster, T. J., 2006. "Less harmful acidic degradation of poly (lacticco-glycolic acid) bone tissue engineering scaffolds through titania nanoparticle addition." Int. J. Nanomedicine, vol. 1, pp. 541-545.

[30] Joseph Francis, P. J. and Arun, K. J., 2018. "Navas aa and irene joseph, biomedical applications of polymers -an overview." vol. 15,

[31] Kratz, F., 2008. "Albumin as a drug carrier: design of prodrugs, drug conjugates and nanoparticles." $J$. Control Release, vol. 132, pp. 171-183.

[32] Freyman, T. M., Yannas, I. V., Yokoo, R., and Gibson, L. J., 2001. "Fibroblast contraction of a collagenGAG matrix." Biomaterials, vol. 22, pp. 2883-2891.

[33] Marijnissen, W. J. C. M., van Osch, G. J. V. M., and Aigner, J., 2002. "Alginate as a chondrocyte-delivery substance in combination with a non-woven scaffold for cartilage tissue engineering." Biomaterials, vol. 23 , pp. 1511-1517.

[34] Park, H., Choi, B., Hu, J., and Lee, M., 2013. "Injectable chitosan hyaluronic acid hydrogels for cartilage tissue engineering." Acta Biomater, vol. 9, pp. 4779-4786.

[35] Lenaghan, S. C., Serpersu, K., Xia, L., He, W., and Zhang, M. A., 2011. "Naturally occurring nanomaterial from the Sundew (Drosera) for tissue engineering." Bioinspir Biomim, vol. 6,

[36] Huang, Y., Wang, Y. J., and Wang, Y., 2015. "Exploring naturally occurring ivy nanoparticles as an alternative biomaterial." Acta Biomater, vol. 25, pp. 268-283.

[37] Richard, S., Maxwell, M., Chenshuang, L., Kang, T., Chia, S., and Zhong, Z. "Current development of biodegradable polymeric materials for biomedical applications." Drug Design, Development and Therapy, Dovepress,

[38] King, A. H., 1983. "Brown seaweed extracts (Alginates)." Food Hydrocolloids, vol. 2, pp. 115-188.

[39] Jong-Whan, R., 2004. "Physical and mechanical properties of water resistant sodium alginate films." Elsevier, Lebensm Wiss. U. Technol, vol. 37, pp. 323-330.

[40] Grant, G. T., Morris, E. R., Rees, D. A., Smith, P. J. C., and Thom, D., 1973. "Biological interactions between polysaccharides and divalent cations, The egg-box model." FEBS Letters, vol. 32, pp. 195-198.

[41] Jinchen, S. and Huaping, T., 2013. "Alginate-based biomaterials for regenerative medicine applications." Materials, vol. 6, pp. 1285-1309.

[42] Stevens, M. M., Qanadilo, H. F., Langer, R., and Shastri, V. P., 2004. "A rapid-curing alginate gel system: Utility in periosteum-derived cartilage tissue engineering." Biomaterials, vol. 25, pp. 887-894.

[43] Kuo, C. K. and Ma, P. X., 2001. "Ionically crosslinked alginate hydrogels as scaffolds for tissue engineering: Part 1. Structure, gelation rate and mechanical properties." Biomaterials, vol. 22, pp. 511-521.

[44] Pawar, S. N. and Edgar, K. J., 2012. "Alginate derivatization: A review of chemistry, properties and applications." Biomaterials, vol. 33, pp. 3279-3305.

[45] Lee and Mooney, D. J., 2012. "Alginate: Properties and biomedical applications." Progress Polymer Science, vol. 37, pp. 106-126.

[46] Chandika, P., Ko, S. C., and Oh, G. W., 2015. "Fish collagen/alginate/chitooligosaccharides integrated scaffold for skin tissue regeneration application." Int. J. Biol Macromol, vol. 81, pp. 504-513.

[47] Ruvinov, E. and Cohen, S., 2016. "Alginate biomaterial for the treatment of myocardial infarction: Progress, translational strategies, and clinical outlook: From ocean algae to patient bedside." Adv. Drug Deliv. Rev., vol. 96, pp. 54-76.

[48] Boateng, J. and Catanzano, O., 2015. "Advanced therapeutic dressings for effective wound healing\&\#x2014; a review." J. Pharm Sci., vol. 104, pp. 3653-3680.

[49] Boateng, J., Burgos-Amador, R., Okeke, O., and H., P., 2015. "Composite alginate and gelatin based biopolymeric wafers containing silver sulfadiazine for wound healing." Int. J. Biol Macromolecules, vol. 79, pp. 63-71.

[50] Balakrishnan, B., Mohanty, M., Umashankar, P. R., and Jayakrishnan, A., 2005. "Evaluation of an in situ forming hydrogel wound dressing based on oxidized alginate and gelatin." Biomaterials, vol. 26, pp. 63356342. 
[51] Kolambkar, Y. M., Dupont, K. M., and Boerckel, J. D., 2011. "Huebsch, N.; Mooney, D.J.; Hutmacher, D.W.; Guldberg, R.E. An alginate-based hybrid system for growth factor delivery in the functional repair of large bone defects." Biomaterials, vol. 32, pp. 65-74.

[52] Nguyen, T. P. and Lee, B. T., 2012. "Fabrication of oxidized alginate-gelatin-BCP hydrogels and evaluation of the microstructure, material properties and biocompatibility for bone tissue regeneration." J. Biomater. Appl., vol. 27, pp. 311-321.

[53] Rubert, M., Monjo, M., Lyngstadaas, S. P., and Ramis, J. M., 2012. "Effect of alginate hydrogel containing polyproline-rich peptides on osteoblast differentiation." Biomed. Mater.,

[54] Xia, Y., Mei, F., Duan, Y., Gao, Y., Xiong, Z., Zhang, T., and Zhang, H., 2012. "Bone tissue engineering using bone marrow stromal cells and an injectable sodium alginate/gelatin scaffold." J. Biomed. Mater. Res., vol. 100, pp. 1044-1050.

[55] Harkness, R. D., 1961. "Biological functions of collagen." Biol. Rev., vol. 36, pp. 399-46.

[56] Gelse, K., Pöschl, E., Aigner, T., and Structure, C., 2003. "Function, and biosynthesis." Advanced Drug Delivery Reviews, vol. 55, pp. 1531-1546.

[57] Lee, Singla, A., and Lee, Y., 2001. "Biomedical applications of collagen." Int. J. Pharmaceut, vol. 221, pp. $1-22$.

[58] Weinberg, C. B. and Bell, E., 1986. "A blood vessel model constructed from collagen and cultured vascular cells." Science, vol. 231, pp. 397-400.

[59] Angele, P., Abke, J., Kujat, R., Faltermeier, H., Schumann, D., and Nerlich, M., 2004. "Influence of different collagen species on physico-chemical properties of crosslinked collagen matrices." Biomaterials, vol. 25, pp. 2831-2841.

[60] Yaylaoglu, M. B., Yildız, C., Korkusuz, F., and Hasırc1, V., 1999. "Novel osteochondral implant." Biomaterials, vol. 20, pp. 1513-1520.

[61] Daamen, W. F., van Moerkerk, H. T. B., Hafmans, T., Buttafoco, L., Poot, A. A., and Veerkamp, J. H., 2003. "Preparation and evaluation of molecularly-defined collagen-elastin-glycosaminoglycan scaffolds for tissue engineering." Biomaterials, vol. 24, pp. 4001-4009.

[62] Liu, Thompson, A. Y., Heidaran, M. A., Poser, J. W., and Spiro, R. C., 1999. "An osteoconductive collagen/hyaluronate matrix for bone regeneration." Biomaterials, vol. 20, pp. 1097-1108.

[63] Rao, J. K., Ramesh, D. V., and Rao, K. P., 1994. "Implantable controlled delivery systems for proteins based on collagenpHEMA hydrogels." Biomaterials, vol. 15, pp. 383-389.

[64] Woerly, S., Marchand, R., and Lavallée, G., 1991. "Interactions of copolymeric poly(glyceryl methacrylate)-collagen hydrogels with neural tissue: effects of structure and polar groups." Biomaterials, vol. 12, pp. 197-203.

[65] Glowacki, J. and Mizuno, S., 2008. "Collagen scaffolds for tissue engineering." Biopolymers, vol. 89, pp. 338-344.

[66] Soltysiak, P., Hollwarth, M. E., and Saxena, A. K., 2010. Bio-Med. Mater. Eng., vol. 20, pp. 1-11.

[67] Komura, M., Komura, H., Kanamori, Y., Tanaka, Y., Suzuki, K., Sugiyama, M., Nakahara, S., Kawashima, H., Hatanaka, A., et al., 2008. Pediatr. Surg., vol. 43, pp. 2141-2146.

[68] Asmi, 2003. "Overview of biomaterials and their use in medical devices." Handbook of Materials for Medical Devices, Available: http://asmiinternational.org/bookstore

[69] Lee, Jeon, H. W., and Lee, Y. W., 2003. "Artificial dermis composed of gelatin, hyaluronic acid and (1-3), (1-6), - $\beta$ - Glucan." Macromolecular Research, vol. 11, pp. 368-374.

[70] Wood, J., 2003. "Tissue-like constructs made in minutes." Materials Today, vol. 8, p. 22.

[71] Berthold, A., Cremer, K., and Kreuter, J., 1998. "Collagen microparticles: carriers for glucocorticosteroids." Eur. J. Pharm. Biopharm., vol. 45, pp. 23-29.

[72] Agargel. Available: www.Agargel./carrageenan-tec.html

[73] Introduction to Carrageenan - Structure. "Cybercolloids."

[74] Lev, R., Long, R., Mallonga, L., Schnaram, R., and Reily, W., 1997. "Evaluation of Carrageenan as Base for Topical Gels." Pharm Res., vol. 14, p. 42.

[75] Lui, Y., Schnaram, R., and Reily, W., 1997. "Evaluation of carrageenan as suppository base." Pharm Res., vol. 14 , p. 41.

[76] Abida Kalsoom, K., Ain Us, S., Shamyla, N., and Fahad, A., 2017. "Carrageenan based bionanocomposites as drug delivery tool with special emphasis on the influence of ferromagnetic nanoparticles, US National Library of Medicine National Institutes of Health." Oxid Med Cell Longev,

[77] Onishi, T., Umemura, S., Yanagawa, M., Matsumura, M., Sasaki, Y., and Ogasawara, T., 2008. "Remineralization effects of gum arabic on caries-like enamel lesions." Arch Oral Biol., vol. 53, pp. 257260.

[78] Agar-agar Review Sheet, 1995. "USDA Organic Materials Review."

[79] About Agar Pre-Embedding in Histopathology.

[80] Agar Archived, 2007. "At the Wayback Machine. at lsbu.ac.uk water structure and science,."

[81] EnricaCaló, V. and Khutoryanskiy, V., 2015. "Biomedical applications of hydrogels: A review of patents and commercial products." European Polymer Journal, vol. 65, pp. 252-267.

[82] Yahia, L. H., Chirani, N., and Gritsch, L., 2015. "History and applications of hydrogels." J. Biomedical Sci., vol. 4 , p. 2. 
[83] Young, S., Wong, M., Tabata, Y., and Mikos, A. G., 2005. "Gelatin as a delivery vehicle for the controlled release of bioactive molecules." J. Controlled Release, vol. 109, pp. 256-274.

[84] Mariod, A. A. and Adam, H. F., 2013. "Review: gelatin, source, extraction and industrial applications." Acta Sci Pol Technol Aliment., vol. 12, pp. 135-147.

[85] Balassa, L. L. and Fanger, G. O., 1971. "Microencapsulation in the food industry." CRC Critical Reviews in Food Technology, vol. 2, pp. 245-265.

[86] Hebert, G. D. and Holloway, O. E., 1992. "Product and process of coating nuts with edible protein. U.S. patent." vol. 5, p. 562.

[87] Burke, C. J., Hsu, T. A., and Formulation, V. D. B., 1999. "stability, and delivery of live attenuated vaccines for human use." Crit Rev Ther Drug Carrier Syst., vol. 16, pp. 1-83.

[88] Yao, K., Mao, J., and Yin, J., 2002. "“Chitosan/gelatin network based biomaterials in tissue engineering." Biomedical Engineering Applications Basis and Communications, vol. 14, pp. 115-121.

[89] Foox, M. and Zilberman, M., 2015. "Drug delivery from gelatin-based systems." Expert Opin Drug Deliv., vol. 12, pp. 1547-1563.

[90] Ozkizilcik, A. and Tuzlakoglu, K., 2014. "A new method for the production of gelatin microparticles for controlled protein release from porous polymeric scaffolds." J. Tissue Eng Regen Med., vol. 8, pp. 242-247.

[91] Cohen, B., Shefy-Peleg, A., and Zilberman, M., 2014. "Novel gelatin/alginate soft tissue adhesives loaded with drugs for pain management: structure and properties." J. Biomater. Sci. Polym. Ed., vol. 25, pp. 224 240 .

[92] Malafaya, P. B., Silva, G. A., and Reis, R. L., 2007. "Natural-origin polymers as carriers and scaffolds for biomolecules and cell delivery in tissue engineering applications." Adv. Drug. Del. Rev., vol. 59, pp. 207233.

[93] Bigi, A., Cojazzi, G., Panzavolta, S., Roveri, N., and Rubini, K., 2002. "Stabilization of gelatin films by crosslinking with genipin." Biomaterials, vol. 23, pp. 4827-4832.

[94] Sugih, A. K., 2008. Synthesis and properties of starch based biomaterials Ph.D. thesis. The Netherlands: University of Groningen, Groningen.

[95] Vengal, J. C. and Srikumar, M., 2005. "Processing and study of novel lignin-starch and lignin-gelatin biodegradable polymeric films." Trends in Biomaterials and Artificial Organs, vol. 18, pp. 237-241.

[96] Marques, A. P., 2004. Biofunctionality and immunocompatibility of starch-based biomaterials. Ph.D. thesis, Departmento engenharia polimerios, Universidale Do Minho, Escola de Engenharia.

[97] Galliard, T. and Bowler, P., 1987. "Morphology and composition of starch." Crit Rep. Appl. Chem., vol. 13, pp. 55-78.

[98] Griffin, G. J. L., 1994. Particulate starch based products. In: Gjl g, editor. Chemistry and technology of biodegradable polymers. Glasgow: Blackie Academic \& Professional. pp. 18-47.

[99] Gomes, M. E., Godinho, J. S., Tchalamov, D., Cunha, A. M., and Reis, R. L., 2002. "Alternative tissue engineering scaffolds based on starch: processing methodologies, morphology, degradation and mechanical properties." Mater. Sci. Eng., vol. 20, pp. 19-26.

[100] Gomes, M. E., Ribeiro, A. S., Malafaya, P. B., Reis, R. L., and Cunha, A. M., 2001. "A new approach based on injection moulding to produce biodegradable starch-based polymeric scaffolds: morphology, mechanical and degradation behaviour." Biomaterials, vol. 22, pp. 883-889.

[101] Dragan, E. S., 2014. "Design and applications of interpenetrating polymer network hydrogels." A Review. Chem Eng J., vol. 243, pp. 572-590.

[102] Mahdieh, Z., Bagheri, R., Eslami, M., Amiri, M., Shokrgozar, M. A., and Mehrjoo, M., 2016. "Thermoplastic starch/ethylene vinyl alcohol/forsterite nanocomposite as a candidate material for bone tissue engineering." Mater Sci Eng C., vol. 69, pp. 301-310.

[103] Olivato, J. B., Müller, C. M. O., Carvalho, G. M., Yamashita, F., and Grossmann, M. V. E., 2014. "Physical and structural characterisation of starch/polyester blends with tartaric acid." Mater. Sci. Eng. C., vol. 39, pp. 35-39.

[104] Ali Akbari, G. S., Ebrahimzadeh, M. H., Solati-hashjin, M., and Abu Osman, N. A., 2014. "Polycaprolactone/starch composite: Fabrication, structure, properties, and applications." J. Biomed. Mater. Res. A, vol. 103, pp. 2482-2498.

[105] Salgado, A. J., Gomes, M. E., Chou, A., Coutinho, O. P., Reis, R. L., and Hutmacher, D. W., 2002. "Preliminary study on the adhesion and proliferation of human osteoblasts on starch-based scaffolds." Mater. Sci. Eng. C., vol. 20, pp. 27-33.

[106] Klemm, D., Schmauder, H. P., and Heinze, C. T., 2002. In: Steinbüchel a, editor. Biopolymers. Weinheim: WILEY-VCH. pp. 275-319.

[107] Drury, J. L. and Mooney, D. J., 2003. "Hydrogels for tissue engineering: Scaffold design variables and applications." Biomaterials, vol. 24, pp. 4337-4351.

[108] Czaja, W., Krystynowicz, A., Bielecki, S., and Brown, J. R. M., 2006. "Microbial cellulose-the natural power to heal wounds." Biomaterials, vol. 27, pp. 145-151.

[109] Jia, H., Jia, Y., Wang, J., Hu, Y., Zhang, Y., and Jia, S., 2009. "Potentiality of bacterial cellulose as the scaffold of tissue engineering of cornea." In Biomedical Engineering and Informatics, 2009 BMEI '09 2nd International Conference on; 2009 17-19 Oct. 2009. pp. 1-5.

[110] Svensson, A., Nicklasson, E., Harrah, T., Panilaitis, B., Kaplan, D. L., and Brittberg, M., 2005. "Bacterial cellulose as a potential scaffold for tissue engineering of cartilage." Biomaterials, vol. 26, pp. 419-431. 
[111] Hong, L., Wang, Y. L., Jia, S. R., Huang, Y., Gao, C., and Wan, Y. Z., 2006. "Hydroxyapatite/bacterial cellulose composites synthesized via a biomimetic route." Mater Lett, vol. 60, pp. 1710-1713.

[112] Wan, Y. Z., Huang, Y., Yuan, C. D., Raman, S., Zhu, Y., and Jiang, H. J., 2007. "Biomimetic synthesis of hydroxyapatite/bacterial cellulose nanocomposites for biomedical applications." Mater. Sci. Eng. C., vol. 27, pp. 855-864.

[113] Kas, H. S., 1997. "Chitosan: Properties, preparation and application to microparticulate systems." $J$. Microencapsul, vol. 14, pp. 689-711.

[114] Singla, A. K. and Chawla, M., 2001. "Chitosan: Some pharmaceutical and biological aspects-An update." J. Pharm. Pharmacol., vol. 53, pp. 1047-1067.

[115] Kumar, M. N. V. R., Muzzarelli, R. A. A., Muzzarelli, C., Sashiwa, H., and Domb, A. J., 2004. "Chitosan chemistry and pharmaceutical perspectives." Chem Rev., vol. 104, pp. 6017-6084.

[116] Dongying, Z., Shuang, Y., Beini, S., Shuang, G., Sihan, G., and Kai, Z., 2018. "Biomedical applications of chitosan and its derivative nanoparticles." Polymers, vol. 10, p. 462.

[117] Dina, R. and Hans-Georg, S., 2009. "Chitosan and its antimicrobial potential - a critical literature survey." Microb Biotechnol., vol. 2, pp. 186-201.

[118] Jin, H. J., Park, J., Valluzzi, R., Cebe, P., and Kaplan, D. L., 2004. "Biomaterial films of bombyx mori silk fibroin with poly(ethylene oxide)." Biomacromolecules, vol. 5, pp. 711-717.

[119] Kim, I. Y., Seo, S. J., and Moon, H. S., 2008. "Chitosan and its derivatives for tissue engineering applications." Biotechnol Adv., vol. 26, pp. 1-21.

[120] Wang, 2003. "Developing bioactive composite materials for tissue replacement." Biomaterials, vol. 24, pp. 2133-51.

[121] Tokoro, A., Tatewaki, N., Suzuki, K., Mikami, T., Suzuki, S., and Suzuki, M., 1988. "Growth-inhibitory effect of hexa-N-acetylchitohexaose and chitohexaose against Meth-A solid tumor." Chem. Pharm. Bull., vol. 36, pp. 784-790.

[122] Yang, Shim, W. S., Cui, F. D., Cheng, G., Han, X., Jin, Q. R., Kim, D. D., Chung, S. J., and Shim, C. K., 2009. "Enhanced electrostatic interaction between chitosan-modified PLGA nanoparticle and tumor." Int. J. Pharm., vol. 371, pp. 142-147.

[123] Wang, Gu, Y., Zhou, Q., Ma, G., Wan, Y., and Su, Z., 2006. "Preparation and characterization of uniformsized chitosan microspheres containing insulin by membrane emulsification and a two-step solidification process." Colloids Surf. B Biointerfaces, vol. 50, pp. 126-135.

[124] Ozbas-Turan, S., Aral, C., Kabasakal, L., Keyer-Uysal, M., and Akbuga, J., 2003. "Co-encapsulation of two plasmids in chitosan microspheres as a non-viral gene delivery vehicle." J. Pharm. Pharm. Sci., vol. 6, pp. 27-32.

[125] Ahmed, T. A. E., Dare, E. V., and Hincke, M., 2008. "Fibrin: A versatile scaffold for tissue engineering applications." Tissue Engineering Part B,

[126] Mcgill, V., Kowal-Vern, A., and Lee, M., 1997. "Use of fibrin sealant in thermal injury." J. Burn. Care Rehabil., vol. 18, pp. 429-434.

[127] Briganti, E., Spiller, D., and Mirtelli, C., 2010. "A composite fibrin-based scaffold for controlled delivery of bioactive pro-angiogenetic growth factors." J. Control Release, vol. 142, pp. 14-21.

[128] De La, P. P. and Ludeña, D., 2014. "Cell culture in autologous fibrin scaffolds for applications in tissue engineering." Exp. Cell Res., vol. 322, pp. 1-11.

[129] Jackson, M. R., Macphee, M. J., Drohan, W. N., and Alving, B. M., 1996. "Fibrin sealant: Current and potential clinical applications." Blood Coagul Fibrinolysis, vol. 7, pp. 737-746.

[130] Pradeep, A. R., Nagpal, K., Karvekar, S., Patnaik, K., Naik, S. B., and Guruprasad, C. N., 2015. "Plateletrich fibrin with $1 \%$ metformin for the treatment of intrabony defects in chronic periodontitis: A randomized controlled clinical trial." J. Periodontol., vol. 86, pp. 729-737.

[131] Laurent, T. C., Laurent, U. G., and Fraser, J. E., 1995. "Functions of hyaluronan." Ann. Rheum. Dis., vol. 54, pp. 429-432.

[132] Lee, Jeon, H. W., and Lee, Y. W., 2003. "Artificial dermis composed of gelatin, hyaluronic acid and (1-3), (1-6), - $\beta$ - Glucan." Macromolecular Research, vol. 11, pp. 368- 374.

[133] Prestwich, G. D., 2011. "Hyaluronic acid-based clinical biomaterials derived for cell and molecule delivery in regenerative medicine." J. Control Release., vol. 115, pp. 193-199.

[134] Choi, K. Y., Chung, H., Min, K. H., Yoon, H. Y., Kim, K., Park, J. H., Kwon, I. C., and Jeong, S. Y., 2010. Biomaterials, vol. 31, pp. 106-114.

[135] Allison, D. D. and Grande-Allen, K. J., 2006. "Hyaluronan, A powerful tissue engineering tool." Tissue Engineering, vol. 12, pp. 2131-2140.

[136] Kato, Y., Nakamura, S., and Nishimura, M., 2006. "Beneficial actions of hyaluronan (HA) on arthritic joints: Effects of molecular weight of HA on elasticity of cartilage matrix." Biorheology, vol. 43, pp. 347354.

[137] David, F. W., 2009. "On the nature of biomaterials." Elsevier, Biomaterials, vol. 30, pp. 5897-5909. 